\title{
ПРИМЕНЕНИЕ ЭЛЕКТРОРАЗВЕДКИ ВРЭ-ВП ПРИ ПОИСКАХ МЕСТОРОЖДЕНИЙ НЕФТИ И ГАЗА В УСЛОВИЯХ СОЛЯНО-КУПОЛЬНОЙ ТЕКТОНИКИ.
}

Нестерова О.Г., Тертыиников К.В.

(ЗАО «НПЦ» Геонефтегаз»)

Практика нефтепоксковых работ свидетельствует об актуальности и промышленной значимости использования злектроразведки высокого разрешения с измерением параметра вызванной поляризачии (ВРЭ-ВП) в комплексе с сейсморазведкой при поиске и разведке новьг объектов в сложньг геологических условиях.

Особенности геологического строення: соляно-купольная тектоника, большие углы падения пластов, литологические замещения - добавляют дополнительные трудности при анализе данњых. Для наиболее достоверного прогноза залежей углеводородов и моделирования месторождений необходимо привлекать пирокий комплекс геофизических методов.

Электроразведочные методики являются часто необходимым дополнением к сейсморазведочным работам, т.к. электроразведка является методом, имегощим физические основы для поиска нефти и газа.

На территории Казахстана, в условиях соляно-купольной тектоники, где залежи располагаются под мощным слоем соляных куполов роль электроразведки трудно переоценить. Известно, что мощный непроводящий слой соли является экраном для электрической компоненты, но благодаря методике, реализованной в технологии ВРЭ-ВП, позволяющей проводить двухкомпонентные измерения (электрическая компонента $\mathrm{Ex}$ и вертикальная магнитная компонента $\mathrm{dBz} / \mathrm{dt}$ ). Для магнитной компоненты соль не является преградой, что позволяет применять данный метод для поиска и разведки подсолевьх отложений.

Технология полевьх работ и интерпретации высокоразретающей частотно-временной электроразведки с измерением параметра вызванной поляризация (ВРЭ-ВП), объединяет в себе достоинства изучения нестационарного процесса в части высокого разрешения геоэлектрического разреза и измерения фазовых параметров гармонического поля с целью получения информации об аномалиях вызванной поляризации, непосредственно связанных с залежами углеводородов.

Такая технология позволяет получать информацию о модели геологической среды, аномалиях вызванной поляризации и осуществлять их привязку по глубине на основе решения обратной задачи в гармонхческой области и анализа динамических и временных характеристик временных электроразведочных разрезов.

Использование этой технологии позволяет: в частотной области изучать удельную электропроводность и вызванную поляризацию горных пород, аномалии которых связаны с залежами углеводородов, а во временной области выполнять анализ временных и динамических характеристик нестационарного поля и осуществлять глубннную привязку выделенных электроразведочньх аномалий на ос- нове совместного анализа с данными ГИС и сейсморазведки.

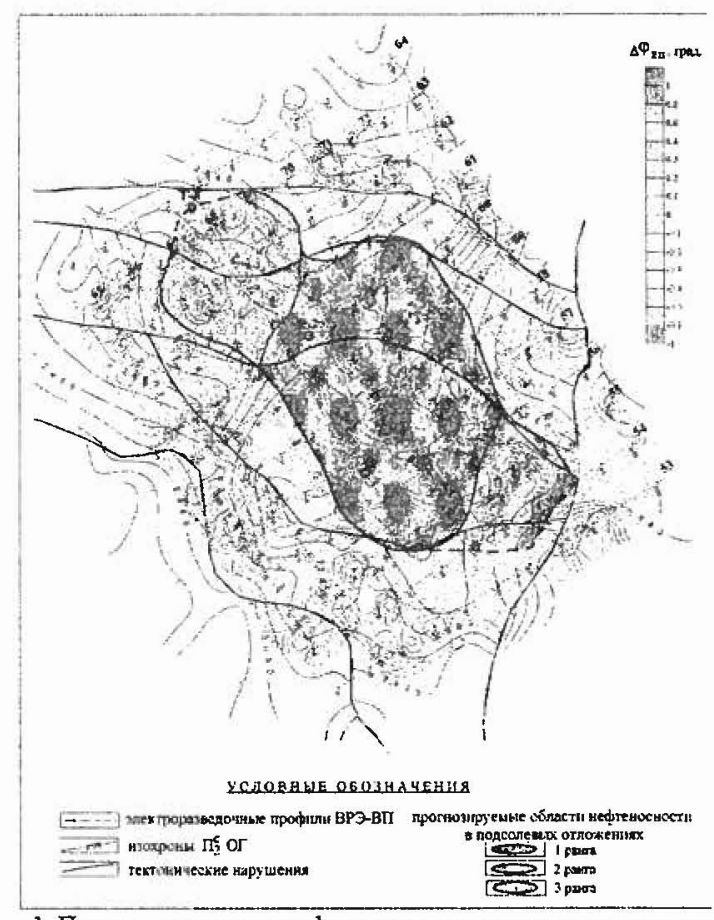

Рис. 1 Пример прогноза нефтеносности подсолевых отложений по данњым ВРЭ-ВП (Казахстан)

Теоретические исследования и результаты полевых электроразведочных работ показали высокую корреляционную связь аномалий вызванной поляризации с местоположением залежи. В частности, наблюдается уменьшение кажущейся поляризуемости над продуктивными зонами, и образуются локальные аномалии повышенной поляризуемости над контурами нефтяных залежей.

Интерпретация результатов измерений фазового параметра ВП заключалась, в основном, в профильной и площадной пространственной фильтрации с целью выделения локальных аномалий вызванной поляризации.

Применение трехмерного математического моделирования позволило учесть влияние соляного купола на электроразведочные данные.

На рисунке 1 представлены результаты комплексной интерпретации данных сейсморазведки и электроразведки ВРЭ-ВП. На основе распределения аномалий фазового параметра были выделены контуры нефтеносности в подсолевых отложениях. Выделенные объекты согласуютея со структурным планом по кровле продуктивного горизонта.

Можно с уверенностью сказать, что применение электроразведки при поиске углеводородов в условиях соляно-купольной тектоники значительно увеличивает вероятность обнаружения залежей. 